УДК 378+37.091.313+37.014.68-043.5

Сінельнікова Наталія Олегівна

кандидат педагогічних наук

Київський університет імені Б. Грінченка, м. Київ, Україна

ORCID 0000-0003-0095-8449

n.sinelnikova@kubg.edu.ua

\title{
ПІДГОТОВКА МАЙБУТНІХ УЧИТЕЛІВ ПОЧАТКОВОЇ ШКОЛИ ДО ПЕДАГОГІЧНОЇ ВЗАЕМОДІЇ $З$ БАТЬКАМИ ЗАСОБАМИ ІКТ
}

\begin{abstract}
Анотація. Представлена на розгляд стаття окреслює сучасну проблему 3 підготовки вчителів початкової школи - їх готовність до роботи з батьками. У процесі дослідження виявлено, що найбільш ефективним у підготовці майбутніх фахівців $\epsilon$ використання сучасних інтерактивних форм роботи та інформаційно-комунікаційних технологій (ІКТ) під час проведення лекційних, семінарських та практичних занять. Для комплексного вивчення цієї проблеми було проведено поглиблений аналіз праць вітчизняних та зарубіжних науковців. Представлені результати опитування та анкетування студентів IV курсу спеціальності «Початкова освіта» Педагогічного інституту Київського університету імені Бориса Грінченка надали уявлення про обсяг і грунтовність знань з означеної проблеми, зумовили іiі актуальність та завдання. У ході дослідження визначено необхідні компоненти готовності студентів до роботи з батьками - когнітивний, емоційний, психологічний, праксеологічний, риторичні уміння. Викладено результати розробленої системи навчальних занять із застосуванням різних інтерактивних форм роботи та засобів ІКТ і доведено іiі дієвість. Педагогічне дослідження проводилося у три етапи - констатувальний, формувальний та контрольний експеримент. Результативність розробленої системи відображено в порівняльній діаграмі, відповідно до даних анкетування контрольної та експериментальної груп на контрольному етапі дослідження. Представлені дані свідчать про необхідність проведення додаткових заходів, спрямованих на підвищення рівня готовності майбутніх учителів початкової школи до педагогічної взаємодії з батьками засобами інтерактивних форм роботи й інформаційно-комунікаційних технологій. Результати дослідження демонструють необхідність підвищення риторичних умінь та праксеологічного компоненту готовності майбутніх вчителів початкової школи до роботи 3 батьками. Для досягнення цієї мети доцільно впроваджувати в освітній процес закладів вищої освіти пропоновану систему роботи зі студентством.
\end{abstract}

Ключові слова: підготовка студентів; педагогічна взаємодія; батьки; інтерактивні форми роботи; інформаційно-комунікаційні технології (ІКТ); компоненти та рівні готовності студентів до педагогічної взаємодії з батьками.

\section{1. ВСТУП}

Постановка проблеми. Існує чимало всесвітніх практик, які спрямовані на підвищення рівня якості освіти. Сучасні заклади вищої освіти проводять планомірну цілеспрямовану роботу щодо активізації, організації, методичного й інформаційного супроводу освітнього процесу. Такий підхід до організації навчального процесу $\epsilon$ досить типовим для багатьох європейських країн, що стосується України, то певні результати вже зараз можемо спостерігати у Київському університеті імені Бориса Грінченка.

Відповідно до плану роботи університету на 2017-2018 н. р. пріоритетами його діяльності $\epsilon$ [1]:

- упровадження і реалізація нової освітньої стратегії університету як системи забезпечення якості освіти;

- виконання корпоративних стандартів університету; 
- інтернаціоналізація діяльності університету;

- розвиток якісного єдиного електронного інформаційно-освітнього середовища університету;

- забезпечення політики відкритості університету;

- розвиток корпоративної культури лідерства служіння.

Передусім звернемо увагу на перший пункт - упровадження і реалізація нової освітньої стратегії університету як системи забезпечення якості освіти. На наш погляд, вона безпосередньо реалізується через оновлення змісту, форм та методів викладання в університеті.

Особливої актуальності набуває створення і практико-орієнтована діяльність Центрів компетентностей. Вони надають можливість у спеціально створеному середовищі здобути потрібні вміння i практичні навички задля формування спеціальних (фахових, предметних) компетентностей, необхідних для подальшої ефективної професійної діяльності.

Центри стають наразі доволі помітним і дієвим засобом для оптимізації освітнього процесу. Окрім Центрів, що створюються на базі Інститутів, важливу роль відіграють й інші умови, які впливають на процес навчання студента. Це, перш за все, реалізація основних видів навчальних занять, до яких належать:

- - лекція;

- - семінарське, практичне, лабораторне, індивідуальне заняття;

- - консультація.

Специфікою проведення навчальних занять є варіативність баз, на яких їх можна проводити. Ними можуть бути:

- навчальні заклади різних типів - школи, гімназії, ліцеї та ін.;

- освітньо-культурні установи, заклади - музеї, просвітницькі та громадські центри, театри тощо;

- підприємства, установи та організації незалежно від форм власності i господарювання, що надають соціальні послуги особам - Центри соціальних служб для сім’ї, дітей та молоді та ін.

Перелік баз проведення навчальних занять не є повним, адже все залежить від змісту та цілей, які ставить перед собою викладач для того, щоб студент мав можливість краще засвоїти необхідний матеріал.

Акцентуючи увагу на лекційному виді заняття, представимо його нетрадиційні форми проведення, запропоновані науковцями Н. Мачинською та С. Стельмахом [2, c. 15]:

- міні-лекція;

- багатоцільова лекція;

- проблемна лекція;

- лекція-брейнстормінг;

- лекція із заздалегідь запланованими помилками;

- лекція-конференція;

- лекція-прес-конференція;

- лекція-брифінг;

- лекція-круглий стіл;

- лекція-диспут;

- кіно-, відео-лекція;

- лекція-візуалізація;

- лекція-екскурсія;

- лекція із застосуванням техніки зворотного зв'язку (інтерактивна лекція);

- бінарна лекція. 
Також лекція може використовуватися у таких форматах, як:

- перевернуте навчання;

- випереджувальне навчання;

- комбіноване навчання.

Наведені види лекцій допоможуть викладачеві урізноманітнити зміст дисциплін та форму їх подання, що сприятиме зацікавленості студентів.

Що стосується таких видів занять, як семінарське, практичне, лабораторне, індивідуальне, то переваги надаються активним та інтерактивним формам їх проведення. Серед них найдієвішими є:

- тренінгові методики;

- ділові ігри;

- евристичні бесіди;

- дискусії;

- кейс-вправи;

- проектна робота та ін.

Важливим аспектом проведення семінарських занять $є$ дискусійність їх викладу для спонукання студентів до критичного й аналітичного мислення [3, с. 29-30].

Отже, загальна концепція проведення занять має будуватися на засадах партнерської взаємодії, що сприятиме формуванню навичок критичного мислення, активної пізнавальної діяльності, загальних і спеціальних (фахових, предметних) компетентностей, активізації мисленнєвої діяльності [3, с. 29-30].

Згідно з представленими векторами підвищення якості освітнього процесу під час вивчення дисципліни «Технології педагогічної взаємодії вчителя 3 батьками» для студентів IV курсу денної форми навчання спеціальності «Початкова освіта» було застосовано форми і методи роботи, що мали систематичний характер та відповідно до результатів експериментального дослідження були дієвими для запровадження.

Аналіз останніх досліджень і публікацій. Питання педагогічної взаємодії вчителя 3 батьками вивчали як вітчизняні, так i зарубіжні вчені. Науковці Т. Алексєєнко, А. Марушкевич, В. Постовий досліджували напрями взаємодії сім'ї, школи та громадських організацій. Т. Кулікова вивчала шляхи взаємодії сім'ї з іншими соціальними інститутами. Дослідженням дієвих форм роботи з батьками займалися науковці Т. Дем’янюк, Н. Кічук, О. Коберник, Л. Мотрич, В. Ягупов та ін.

Дослідження поглядів наукової спільноти дає підстави стверджувати, що під педагогічною взаємодією вчителя з батьками розуміється їх узгоджена діяльність, спрямована на досягнення спільних цілей і результатів, розв'язання важливих завдань у вихованні й навчанні дитини.

Підготовку вчителя до роботи з батьками вивчали Г. Алфьорова, О. Баранова, Н. Бугаєць, О. Буздуган, С. Корнієнко, О. Матвієнко, А. Шульга та ін. На важливості підготовки вчителя до професійного спілкування наголошувала науковець Г. Алфьорова, вважаючи спілкування основною умовою ефективної співпраці 3 батьками. О. Баранова акцентує увагу на психологічній готовності до роботи 3 батьками. Відповідно до поглядів Н. Бугаєць, під час підготовки до педагогічної взаємодії з батьками важливо формувати готовність до реалізації функцій педагога у взаємодії з родиною [4]. В основі поглядів О. Буздуган покладено дослідження педагогічних умов підготовки майбутніх учителів до педагогічної взаємодії 3 батьками [5]. Науковець О. Матвієнко досліджує проблеми конфліктів батьків і вчителів та шляхи їх вирішення. С. Корнієнко зосереджує увагу на такому аспекті, як професійно-педагогічна готовність до роботи з батьками учнів молодшого шкільного віку. А. Шульга досліджує педагогічні умови підготовки майбутнього вчителя початкової школи до роботи 3 батьками молодших школярів 3 неповних сімей, 
зазначаючи, що основним засобом у такій підготовці є впровадження тренінгових занять [6, с. 9].

Аналіз стану дослідженості наукової проблеми свідчить про недостатній рівень вивчення системи роботи педагогів зі студентами для формування їх готовності до педагогічної взаємодії з батьками. Отже, представлена на розгляд система роботи зі студентами повною мірою заслуговує на увагу.

Мета статті. Виявити, обгрунтувати та дослідити особливості підготовки майбутнього вчителя початкової школи до педагогічної взаємодії з батьками учнів засобами IКТ.

\section{2. МЕТОДИКА ДОСЛІДЖЕННЯ}

У експериментальному дослідженні взяли участь студенти IV курсу денної форми навчання спеціальності «Початкова освіта» у кількості 35 осіб, вік респондентів від 2022 pр. Дослідження реалізовувалося у декілька етапів. Під час першого здійснювався аналіз праць вітчизняних і зарубіжних науковців відповідно до теми дослідження; визначалася актуальність і проблемність представленої теми за допомогою опитування студентів; відповідно до означеної проблеми виокремлено компоненти готовності студентів до роботи з батьками, які вивчалися у ході дослідження; визначалася гіпотеза дослідження. Наступним етапом $є$ анкетування студентів з метою визначення рівня їх готовності до роботи 3 батьками відповідно до розроблених компонентів когнітивного, емоційного, психологічного, праксеологічного, риторичних умінь. Третім етапом була апробація розробленої системи навчальних занять із застосуванням різних інтерактивних форм роботи i засобів IКТ. На четвертому етапі дослідження підтверджено гіпотезу дослідження й узагальнено рекомендації щодо необхідності удосконалення форм роботи зі студентами під час їх підготовки до взаємодії 3 батьками. Відповідно до результатів констатувального експерименту рівні готовності студентів до педагогічної взаємодії з батьками значно підвищилися, особливо їх середній рівень. Заслуговує на увагу врахування того факту, що студентам досить важко навчитися публічно виступати й не боятися аргументувати свої власні погляди батькам. Тому риторичні уміння $є$ проблемними для більшості студентів. Однак загальний рівень готовності студентів значно підвищився, що свідчить про ефективність розробленої системи занять.

\section{3. РЕЗУЛЬТАТИ ДОСЛІДЖЕННЯ}

Однією з найголовніших проблем сучасного педагога $є$ вміння співпрацювати у тандемі з батьками своїх вихованців. Як показує практика, більшість учителів намагається уникати тісних контактів 3 батьками учнів, пояснюючи таку модель поведінки невмінням батьків адекватно сприймати інформацію стосовно їхньої дитини, що в підсумку призводить до певних конфліктних ситуацій. У зв'язку з цим перед сучасними закладами вищої освіти постає доволі назріле питання - підготувити вчителів початкової школи до педагогічної взаємодії з батьками.

Зазначена проблема розкривається під час вивчення студентами IV курсу спеціальності «Початкова освіта» дисципліни «Технології педагогічної взаємодії вчителя 3 батьками». Провівши анкетування серед студентів, у кількості 64 особи, визначили, що більшість з них - 65,6 \% виявляють острах до спілкування з батьками. 15,6 \% - не вважають, що батьки мають впливати на їхню роботу з дітьми, а, отже, спілкування $з$ ними, на їхню думку, може і не відбуватися. 10,9 \% - уміють 
налагоджувати контакти з батьками учнів та ефективно з ними взаємодіяти. Інші 7, 8 \% студентів не визначилися щодо важливості педагогічної взаємодії з батьками учнів. Також результати анкетування свідчать про те, що сучасні студенти потребують практичних порад щодо ефективної взаємодії з батьками своїх майбутніх підопічних.

У цьому контексті вельми важливо навчити студентів цікавим формам і методам роботи 3 батьками. Такими $\epsilon$ інтерактивні форми роботи - тренінги, ділові ігри, батьківські ринги, акваріум, діалог, синтез думок тощо. Майбутні вчителі мають уміти проводити і розробляти індивідуальні бесіди з батьками, батьківські збори, круглі столи, тренінги тощо. Запорукою підвищення їх професійної компетентності $\epsilon$ практична діяльність під час проходження виробничої практики. З’являється можливість відвідати батьківські збори, поспостерігати та поспілкуватися з батьками. Серед завдань виробничої практики зі спеціальності «Початкова освіта» вже з III курсу $\epsilon$ спостереження та проведення батьківських зборів. Тому нині підготовка студентів до інноваційної педагогічної діяльності $\epsilon$ необхідною умовою для актуалізації особистісних знань. Перед студентами потрібно ставити наперед визначене завдання, наприклад, - створити відеозапис з власним виступом перед батьками задля аналізу успіхів і помилок. Така робота надасть їм можливість підвищити свій професійний рівень й обмінятися досвідом з іншими студентами. Такий обмін можна організувати в сучасному додатку Viber або Messeger тощо.

Обмінюватися інформацією під контролем педагога слід за допомогою технології Веб 2.0., а саме - використовуючи блог чи сайт. Використовуючи сервіси для зберігання відео, студенти зможуть удосконалювати свої професійні якості за допомогою педагога й одногрупників, які братимуть участь в обговоренні відеофрагментів батьківських зборів.

Змонтувати відеозображення можна за допомогою таких програм: Movavi, VivaVideo, Video Maker Pro, Magistro, Adobe Premiere Clip та ін.

Для обміну відеоматеріалів доцільно використовувати блог або сайт, створений педагогом. За допомогою облікового запису Google можливо доволі швидко і легко створити веб-сторінку й надати доступ до неї усім бажаючим. Для цього через аккаунт Google потрібно створити веб-сторінку за допомогою GoogleSites - хостингу на базі вікі-рушія.

Педагог здійснює управління сайтом самостійно або може надати доступ для наповнення контентом іншим користувачам. GoogleSites $\epsilon$ доволі легким у користуванні, оскільки надає можливість обмінюватися матеріалами за допомогою різних додатків Google - Документи Google, Календар Google, YouTube, Picasa та ін.

Створити блог можна за допомогою сайта https://www.blogger.com/start. Blogger це безкоштовна служба, що допомагає людям обмінюватися інформацією. Завдяки функціональності цього ресурсу педагог матиме можливість висвітлювати цікаві питання й обмінюватися різного формату інформацією зі студентами. Такий вид роботи дозволить удосконалювати їх практичні вміння [7].

Для того, щоб майбутні вчителі навчилися застосовувати різноманітні форми i методи роботи, викладачеві варто ставити перед студентами завдання - розробити і провести ту форму роботи, яка їм найбільше підходить. Адже так студенти будуть практикувати свої навички, аналізувати свої помилки та вчитися взаємодіяти і впливати на думки інших.

Оскільки для нинішніх студентів важливо орієнтуватися в проблемах сучасної родини, то доцільно запропонувати їм виїзні лекційні, семінарські заняття, майстеркласи, відвідування театрів тощо. Темами вистав можуть бути: «La bonne anna, или Как сохранить семью», «Він і Вона» (показують у Київському академічному драматичному театрі на Подолі), «Всі ми родом із дитинства», «Занадто щасливий батько», «Сімейна 
вечеря» (Національний академічний театр російської драми ім. Лесі Українки), «Мама сказала “Ні”», «Кайдашева сім'я», «Дві сім’ї» (Національний академічний драматичний театр ім. І. Франка) та ін.

Після відвідування театру обов'язково слід проаналізувати переглянуте. Розкрити шляхи розв'язання проблем, висвітлених у виставі, та визначити можливі поради батькам. Найголовніше у такій роботі - навчити студентів аналізувати ситуації i знаходити шляхи їх подолання. На жаль, як свідчить практика, не всі студенти готові до такої діяльності.

Науковці визначають чимало компонентів готовності студентів до взаємодії 3 батьками. На наш погляд, їх варто доповнити: риторичні уміння, когнітивний, емоційний, психологічний, праксеологічний компоненти, що в сукупності демонструють упевненість у власних силах, комунікативність, бажання самоудосконалюватися.

Основними умовами підготовки студентів, на наш погляд, $\epsilon$ : позитивне налаштування їх на ефективну взаємодію з батьками, вселення віри у власні сили у роботі, підбір відеоматеріалів з телепередач та історій на Youtube, що пов'язані 3 проблемами і конфліктами вчителів і батьків, на основі чого робиться аналіз їх взаємодії. Також такі відео допомагають формувати у студентів навички ефективного сприйняття порад щодо взаємовідносин батьків $з$ дітьми.

Одним 3 педагогічно доцільних вважається телеканал «ПЛЮСПЛЮС», на якому є програма «Корисні поради», де розглядаються етичні та психологічні складові розвитку дитини. Такі поради будуть дієвим засобом у роботі з батьками школярів та можуть застосовуватися як під час індивідуальних бесід, так і проведення батьківських зборів.

Не менш дієвим є аналіз студентами ситуацій педагогічного характеру, які так само допомагають їм розкрити свій потенціал і визначити шляхи взаємодії з батьками. Прикладами таких ситуацій можуть подані нижче.

У Вашому класі $є$ обдарована дитина, поясніть батькам, як саме потрібно розвивати эї таланти.

У класі виникла неприємна ситуація - учні побилися між собою. Якою буде Ваша бесіда з батьками?

До Вас у клас має прийти дитина 3 обмеженими фізичними можливостями, розробіть батьківські збори з метою пропедевтики проблем, які можуть виникнути у процесі навчання.

Наведені та схожі ситуації допоможуть у подальшому студентам розв'язувати проблеми, які можуть виникнути в їхній професійній діяльності. Доцільно запропонувати студентам самим розібрати ситуації, які уже траплялися у їхній практичній роботі.

Одначе сучасні студенти мають ще чимало сумнівів щодо правильного розв'язання проблеми, тому їм варто організовувати диспути i дискусії задля переконання один одного у істинності власних тверджень. Ефективним є залучення студентів до співпраці під час лекцій - коли вони заздалегідь шукають цікаву інформацію і демонструють свої дослідження у різних формах - виступ, презентація в Power Point, відео, схеми, таблиці, колажі, буклети тощо.

Для удосконалення умінь студентів взаємодіяти 3 батьками своїх майбутніх вихованців варто проводити практичні заняття. Одним із прикладів такого заняття може бути тема «Умови успішного виховання дитини в родині». Для глибокого розуміння студентами проблеми викладач може запропонувати їм визначити головну, на їх погляд, умову успішного виховання і детально її дослідити, підібрати приклади 3 власного досвіду, з літературних джерел або телепередач, що допоможуть підтвердити ефективність пропонованої умови виховання. Спільний обмін думками між студентами 
допоможе сформувати поради для батьків щодо їх виховного потенціалу. У контексті цього завдання доцільно запропонувати студентам створити блог для батьків, у якому припустимо зазначити рубрики «Успішне виховання», «Проблеми в родині та шляхи їх вирішення», «Що цікавить сучасних дітей?», «Приклади конфліктних ситуацій з дітьми: причини їх виникненні та шляхи подолання» тощо.

Окрім самої форми проведення лекції і семінару, варто видозмінювати і форму прийняття заліку. Як продемонстрував досвід, цікавою формою роботи $є$ проект, який створюють самі студенти. Вони мають самостійно або за допомогою викладача обрати проблему, яка може виникнути в сім’ї, розкрити, як учитель має допомагати батькам та дитині її розв'язати.

Орієнтовним алгоритмом таких проектів є:

1. Постановка проблеми.

2. Визначення мети та засобів її подолання.

3. Опрацювання літератури, необхідної для вивчення визначеної проблеми.

4. Опис діагностичних методик, спрямованих на діагностику проблеми.

5. Визначення методики роботи із сім'єю задля подолання існуючої проблеми. Зазначення необхідності залучення інших фахівців (соціальний педагог, психолог).

6. Апробація розробленої методики роботи з сім'єю.

7. Визначення недоліків у власній роботі та шляхів їх подолання.

8. Демонстрація результатів.

За допомогою такого алгоритму подання проекту студент зможе поглибити свої знання 3 педагогічної взаємодії 3 батьками і реалізувати їх на практиці. Так представлені рекомендації у роботі зі студентами нададуть можливість їм підвищити свій рівень професійної компетентності. Для покращення проекту можна запропонувати студентам попередньо обговорити їх у соціальних мережах UkrOpen,UkrFace, Facebook, Twitter, Tumblr, Google+ тощо.

Зазначені засоби, форми, прийоми та методи роботи сприятимуть формуванню у студентів готовності до реалізації ефективної педагогічної взаємодії з батьками. Так проведено формувальний етап експерименту, під час якого реалізовувалася представлена система навчальних занять із застосуванням різних інтерактивних форм роботи та засобів ІКТ.

Нами було проведено анкетування 3 метою визначення готовності студентів до здійснення педагогічної взаємодії з батьками.

Питаннями анкети були:

Визначення когнітивного компонента.

1. Чи володієте Ви достатньою кількістю знань для педагогічної взаємодії 3 батьками, щоб з впевненістю йти до розв'язання проблем сім'ї?

2. Які форми і методи педагогічної взаємодії з батьками Ви знаєте?

3. Які напрями роботи з батьками Вам відомі?

4. Назвіть інтерактивні форми роботи вчителя з батьками.

Визначення емоційного компонента.

1. Чи завжди Ви готові допомогти сім’'і, яка звернулася за допомогою?

2. Який настрій у Вас виникає перед початком роботи з проблемною сім'єю?

3. Наскільки глибоко Ви переймаєтеся проблемою родини, яка до Вас звернулася?

4. Чи вважаєте за потрібне вселяти віру у батьків щодо $100 \%$ подолання проблеми?

Визначення психологічного компонента.

1. Чи знаєте Ви, як змінити точку зору батьків щодо виховання своєї дитини?

2. Чи вмієте Ви впливати на поведінку інших людей? 
3. Чи вмієте Ви визначати характер відносин у сім’ї без додаткових діагностичних методик?

4. Чи вмієте налаштовувати батьків на активну співпрацю?

Для взаємодії з батьками важливим є вміння вчителя правильно підібрати слова й інтонацію. Оскільки батьки різні і підхід до них так само має бути різним, то варіювання голосом, використання мовленнєвих, риторичних навичок допоможе вчителю ефективно впливати та взаємодіяти з батьками.

Визначення риторичних умінь як компонента риторичної компетентності.

1. Чи в змозі Ви пояснити i довести свою думку, щоб переконати співрозмовника?

2. Чи боїтеся Ви виступати на публіку?

3. Чи вмієте Ви зацікавити аудиторію під час власного виступу?

4. Чи вмієте Ви вирішувати конфліктні ситуації на власну користь?

Визначення праксеологічного компонента.

1. Чи вмієте Ви використовувати форми і методи педагогічного впливу на сім'ю 3 метою оптимізації вирішення проблемних ситуацій?

2. Якими методами і формами роботи Ви володієте досконало?

3. Чи оволоділи Ви вміннями ефективно спілкуватися 3 сім'ями й досягати очікуваного результату?

4. Чи володієте Ви вміннями організовувати і планувати методичну роботу 3 різними категоріями сімей?

Відповідно до зазначених компонентів визначено рівні готовності студентів до педагогічної взаємодії з батьками і зазначено їх показники. Для низького рівня характерні нестійкі знання щодо педагогічної взаємодії вчителя з батьками, відсутність емоційної готовості до взаємодії, небажання їі здійснювати, невміння впливати на думки і погляди інших; недостатній рівень умінь реалізовувати наявні знання на практиці, невміння виступати перед аудиторією.

Студенти, які мають достатній рівень готовності, демонструють поверхові знання 3 педагогічної взаємодії вчителя з батьками; значний рівень емоційної готовності до взаємодії; віру у власні сили, уміння знайти правильні слова для підтримки батьків та їх дитини; значні уміння у варіюванні формами й методами роботи з батьками.

Високий рівень готовності свідчить про грунтовні знання в контексті педагогічної взаємодії з батьками; високий показник готовності до подолання труднощів, які можуть виникнути у роботі із сім'єю; значний рівень психологічної підготовки й оволодіння вміннями впливати на точку зору інших людей, аргументувати власну позицію; оволодіння широким спектром форм і методів роботи з батьками в повсякденній практиці.Рівні готовності студентів до педагогічної взаємодії з батьками під час констатувального експерименту наведені у результатах проведеного анкетування. У контрольній групі задіяно 30 респондентів, а в експериментальній - 34.

Таблиия 1

\section{Результати анкетування контрольної групи на констатувальному етапі дослідження}

\begin{tabular}{|l|l|l|l|l|}
\hline $\begin{array}{l}\text { Рівні готовності } \\
\text { студентів до } \\
\text { педагогічної } \\
\begin{array}{l}\text { взаємодії } 3 \\
\text { батьками }\end{array}\end{array}$ & \multicolumn{5}{|c|}{ Компоненти готовності студентів до педагогічної взаємодії 3} \\
батьками \\
\hline
\end{tabular}




\begin{tabular}{|l|l|l|l|l|l|}
\hline Низький & 3 & 10 & 23 & 18 & 16 \\
\hline Достатній & 17 & 18 & 7 & 10 & 10 \\
\hline Високий & 10 & 2 & - & 2 & 4 \\
\hline
\end{tabular}

Таблиия 2

Результати анкетування експериментальної групи на констатувальному етапі дослідження

\begin{tabular}{|l|l|c|c|c|c|}
\hline $\begin{array}{l}\text { Рівні готовності } \\
\text { студентів до } \\
\text { педагогічної } \\
\begin{array}{l}\text { взаємодії } \\
\text { батьками }\end{array}\end{array}$ & \multicolumn{5}{|c|}{$\begin{array}{l}\text { Компоненти готовності студентів до педагогічної взаємодії } 3 \\
\text { батьками }\end{array}$} \\
\hline & $\begin{array}{l}\text { Когнітив } \\
\text { ний }\end{array}$ & Емоційний & $\begin{array}{l}\text { Психологіч } \\
\text { ний }\end{array}$ & $\begin{array}{l}\text { Праксеоло } \\
\text { гічнй }\end{array}$ & $\begin{array}{l}\text { Риторичні } \\
\text { уміння }\end{array}$ \\
\hline Низький & 6 & 16 & 14 & 17 & 15 \\
\hline Достатній & 20 & 16 & 16 & 13 & 13 \\
\hline Високий & 8 & 2 & 4 & 4 & 6 \\
\hline
\end{tabular}

Відповідно до даних таблиць бачимо, що студентам важче сформувати риторичні та практичні вміння. Тому проводилася робота з урахуванням отриманих даних. Про ефективність іiі проведення свідчать дані таблиць, що відображають результати контрольного етапу експерименту.

Таблиия 3

Результати анкетування контрольної групи на контрольному етапі дослідження

\begin{tabular}{|c|c|c|c|c|}
\hline $\begin{array}{l}\text { Рівні готовності } \\
\text { студентів до } \\
\text { педагогічної } \\
\text { взаємодії } 3 \\
\text { батьками }\end{array}$ & \multicolumn{5}{|c|}{ Компоненти готовності студентів до педагогічної взаємодії 3} \\
батьками \\
\hline
\end{tabular}

Таблиия 4

\section{Результати анкетування експериментальної групи на контрольному етапі дослідження}

\begin{tabular}{|l|l|l|l|l|}
\hline $\begin{array}{l}\text { Рівні готовності } \\
\text { студентів до } \\
\text { педагогічної } \\
\begin{array}{l}\text { взаємодії } 3 \\
\text { батьками }\end{array}\end{array}$ & \multicolumn{5}{|c|}{ Компоненти готовності студентів до педагогічної взаємодії 3} \\
батьками \\
\hline
\end{tabular}




\begin{tabular}{|l|l|l|l|l|l|}
\hline Низький & - & - & - & - & 8 \\
\hline Достатній & 24 & 18 & 34 & 23 & 18 \\
\hline Високий & 10 & 16 & - & 11 & 8 \\
\hline
\end{tabular}

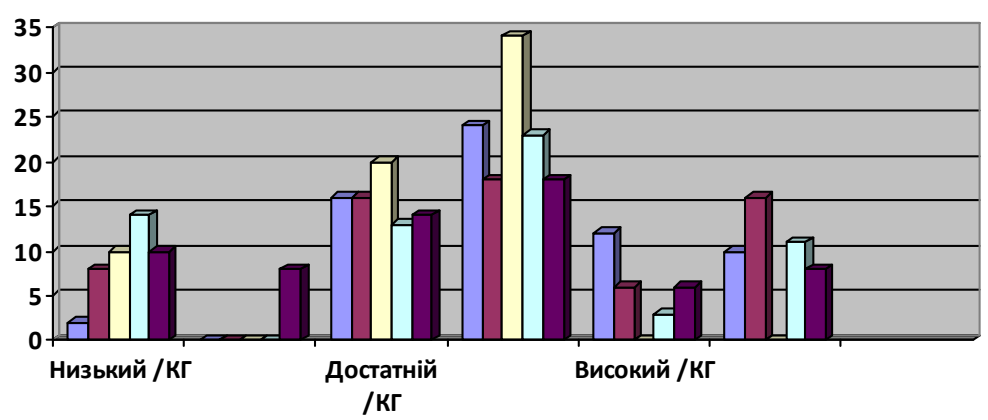

Рис. 1. Динаміка рівнів готовості студентів КГ та ЕГ груп до педагогічної взаємодії з батьками

Проаналізувавши абсолютні величини вибірки можна зробити висновок 3 діаграми щодо ефективності запровадженої системи роботи зі студентами в експериментальній групі. 3 діаграми видно, що низький рівень усіх компонентів готовності студентів до педагогічної взаємодії з батьками в експериментальній групі (ЕГ) наявний лише в риторичних уміннях, а у контрольної групи (КГ) він зменшився, але істотно привалює.

На початковому етапі дослідження нами було визначено гіпотезу, яка полягає в тому, що розроблена й упроваджена система навчальних занять із застосуванням різних інтерактивних форм роботи засобів ІКТ надасть можливість підвищити рівні готовності студентів до педагогічної взаємодії з батьками відповідно до риторичних умінь, когнітивного, емоційного, психологічного, праксеологічного компонентів.

Представлені результати підтверджують висунуту гіпотезу і свідчать про дієвість упровадженої системи роботи зі студентами під час вивчення дисципліни «Технології педагогічної взаємодії вчителя з батьками». Дані таблиць і діаграми демонструють необхідність збільшення практичної роботи серед студентства, надання переваги практичному спілкуванню з батьками, проведення різних форм роботи з батьками під час практичних/семінарських занять 3 метою подолання емоційного та психологічного бар'єрів у спілкуванні з батьками.

\section{4. ВИСНОВКИ ТА ПЕРСПЕКТИВИ ПОДАЛЬШИХ ДОСЛІДЖЕНЬ}

Проведений аналіз літературних джерел свідчить, що підготовка вчителя початкової школи до роботи з батьками - це багатоаспектний процес, що включає накопичення студентами необхідних знань, досвіду та умінь його реалізовувати за рахунок формування професійних та спеціальних компетентностей.

Представлена на розгляд система роботи зі студентами продемонструвала свою ефективність. Відповідно, високі показники експериментальної групи та майже незмінні показники контрольної групи підтверджують необхідність запровадження інтерактивних форм роботи та ІКТ в освітній процес закладів вищої освіти.

Викладачам вишів необхідно приділяти значну увагу урізноманітненню та осучасненню форм і методів роботи зі студентами під час опрацювання доволі складної теми - педагогічна взаємодія з батьками. Особливо важливою $є$ орієнтація на 
практичну підготовку студентів з урахуванням вимог до проведення практики у різних навчальних установах, що додасть їм наснаги розвивати та підвищувати риторичні уміння та праксеологічний компонент готовності до педагогічної взаємодії з батьками.

Однак дослідження не $\epsilon$ вичерпним. Перспективою подальших розвідок $\epsilon$ розроблення Е-портфоліо студентів в електронному середовищі з метою обміну досвідом і накопичення інформації серед студентства.

\title{
СПИСОК ВИКОРИСТАНИХ ДЖЕРЕЛ
}

[1] План роботи Київського університету імені Бориса Грінченка на 2017-2018 н. p. [Електронний pecypc]. Доступно: http://kubg.edu.ua/prouniversitet/vizytivka/plan-roboti-universitetu.html. Дата звернення: лютий 18, 2018.

[2] Мачинська Н. І., Стельмах С. С. Сучасні форми організації навчального процесу у вищій школі: навчально-методичний посібник, Львів : Львівський державний університет внутрішніх справ, 180 c., 2012.

[3] "Положення про організацію освітнього процесу в Київському університеті імені Бориса Грінченка" [Електронний ресурс]. Доступно: http://kubg.edu.ua/component/tz_portfolio/archive.html?year=2017\&month=11.Дата звернення: лютий $28,2018$.

[4] Бугаєць Н. А. “Професійно-педагогічна підготовка майбутніх учителів до роботи з сім'єю учня”, дис. канд. пед. наук, Харків : Харків. держ. пед. ун-т ім. Г. С. Сковороди, 2002.

[5] Буздуган О. А. "Підготовка майбутніх учителів початкових класів до педагогічної взаємодії 3 батьками учнів», дис. канд. пед. наук, Одеса : Держ. заклад “Південноукр. нац. пед. ун-т ім. К. Д. Ушинського", 2013.

[6] Шульга А. "Підготовка майбутнього вчителя початкової школи до роботи з батьками молодших школярів з неповних сімей”, дис. канд. пед., Чернівці : Чернів. нац. ун-т ім. Юрія Федьковича, 2017.

[7] Морзе Н. В., Буйницька О. П. "Підвищення рівня інформаційно-комунікаційної компетентності науково-педагогічних працівників - ключова вимога якості освітнього процесу", Інформаційні технології і засоби, Том 59, №3, с. 189 - 200, 2017.

Матеріал надійшов до редакиії 22.03.2018p.

\section{ПОДГОТОВКА БУДУЩИХ УЧИТЕЛЕЙ НАЧАЛЬНОЙ ШКОЛЫ К ПЕДАГОГИЧЕСКОМУ ВЗАИМОДЕЙСТВИЮ С РОДИТЕЛЯМИ СРЕДСТВАМИ ИКТ}

\author{
Синельникова Наталья Олеговна \\ кандидат педагогических наук \\ Киевский университет имени Б. Гринченко, г. Киев, Украина \\ ORCID 0000-0003-0095-8449 \\ n.sinelnikova@kubg.edu.ua
}

\begin{abstract}
Аннотация. Представленная на рассмотрение статья определяет современную проблему по подготовке учителей начальной школы - их готовность к работе с родителями. В процессе исследования выявлено, что наиболее эффективным в подготовке будущих специалистов является использование современных интерактивных форм работы и информационнокоммуникативных технологий (ИКТ) во время проведения лекционных, семинарских и практических занятий. Для комплексного изучения этой проблемы был проведен углубленный анализ работ отечественных и зарубежных ученых. Представлены результаты опроса студентов IV курса специальности «Начальное образование» Педагогического института Киевского университета имени Бориса Гринченко дали возможность иметь представление об объеме и основательности знаний по обозначенной проблеме, обусловили ее актуальность и задачи. В ходе исследования определены необходимые компоненты готовности студентов к работе с родителями - когнитивный, эмоциональный,
\end{abstract}


психологический, праксеологический, риторические умения. Изложены результаты разработанной системы учебных занятий с применением различных интерактивных форм работы и средств ИКТ и доказана ее действенность. Педагогическое исследование проводилось в три этапа - констатирующий, формирующий и контрольный эксперимент. Результативность разработанной системы отражено в сравнительной таблице, согласно данным анкетирования контрольной группы на контрольном этапе исследования. Представленные данные свидетельствуют о необходимости проведения дополнительных мероприятий, направленных на повышение уровня готовности будущих учителей начальной школы к педагогическому взаимодействию $\mathrm{c}$ родителями средствами информационно-коммуникационных технологий. Результаты исследования показывают необходимость повышения риторических умений и праксеологического компонента готовности будущих учителей начальной школы к работе с родителями. Для достижения этой цели целесообразно внедрять в образовательный процесс высших учебных заведений предлагаемую систему работы со студенчеством.

Ключевые слова: подготовка студентов; педагогическое взаимодействие; родители; интерактивные формы работы; ИКТ; компоненты и уровни готовности студентов к педагогическому взаимодействию с родителями.

\title{
PREPARATION OF FUTURE PRIMARY SCHOOL TEACHERS TO PEDAGOGICAL INTERACTION WITH PARENTS BY THE MEANS OF ICT
}

\author{
Nataliia O. Sinelnikova \\ $\mathrm{PhD}$ of Pedagogical Sciences \\ Borys Grinchenko Kyiv University, Kyiv, Ukraine \\ ORCID 0000-0003-0095-8449 \\ n.sinelnikova@kubg.edu.ua
}

\begin{abstract}
The paper presents a current problem of training the future primary school teachers their ability to interact with parents. The study argues that the most effective training for future specialists is reached by the use of modern interactive forms of work and information and communication technologies (ICT) during lectures, seminars and workshops. During the complex study of this problem, an in-depth analysis of the works by domestic and foreign scholars was carried out. The represented student survey helped to evaluate the scope of knowledge about the issue and corroborated its relevance and objectives. The presented results of the survey of students of the IV course of the specialty «Primary education» at the Pedagogical Institute of the Borys Grinchenko Kyiv University provided an idea of the scope and depth of knowledge on the identified problem. During the research we outlined some necessary components promoting readiness for teacher - parent interaction, among them cognitive, emotional, psychological, praxeological components and rhetorical skills. The results of the developed training system with the use of various interactive forms of work and ICT tools are presented and its efficiency tested and proved. The pedagogical study was carried out in three stages - the recording, forming and control experiment. The effectiveness of the developed system is reflected in the comparative table, according to the data of the questionnaire of the control group in the control phase of the study. The presented data testify to the necessity of additional measures aimed at increasing the readiness of future teachers of elementary school for pedagogical interaction with parents through means of information and communication technologies. The results of the study demonstrate the need to increase the rhetorical skills and the praxis component of the readiness of future primary school teachers to work with their parents. To achieve this goal it is expedient to introduce the proposed system of work with students in the educational process of institutions of higher education.
\end{abstract}

Keywords: preparation of students; pedagogical interaction; parents; interactive forms of work; ICT; components and levels of readiness of students for pedagogical interaction with parents. 


\section{REFERENCES (TRANSLATED AND TRANSLITERATED)}

[1] Plan of work of the Boris Grinchenko University of Kyiv for 2017-2018. p [online]. Available: http://kubg.edu.ua/prouniversitet/vizytivka/plan-roboti-universitetu.html. Date of appeal: February 18, 2018 (in Ukrainian).

[2] Machynska N.I., Stelmakh S.C. Modern forms of organization of the educational process in the high school: a teaching manual, Lviv : Lviv State University of Internal Affairs, 180 p., 2012 (in Ukrainian).

[3] "Regulations on the organization of educational process at the Boris Grinchenko University of Kyiv" [online]. Available: http://kubg.edu.ua/component/tz_portfolio/archive.html?year=2017\&month=11.Date of appeal: February 28, 2018 (in Ukrainian).

[4] Bugaets N. A. "Professional-pedagogical preparation of future teachers for work with a student's family", diss. cand. ped. sciences, Kharkiv: Kharkiv. state ped Un-t them. G.S. Skovoroda, 2002 (in Ukrainian).

[5] Buzudugan O. A. "Preparation of future teachers of elementary school for pedagogical interaction with parents of students", diss. cand. ped. sciences, Odessa: State institution "South Caucus of the National Pedagogical University named after K. D. Ushinsky ”, 2013 (in Ukrainian).

[6] Shulga A. "Preparation of the future teacher of elementary school for work with parents of junior schoolchildren from single-parent families", diss. cand. ped. sciences, Chernivtsi: Cherniv. nats Un-t them. Yuri Fedkovich, 2017 (in Ukrainian).

[7] Morse N.V., Buynitska O.P. "Increasing the level of information and communication competence of scientific and pedagogical workers - a key requiremence of the quality of educational process", Information Technologies and Tools, Vol. 59, No. 3, p. 189 - 200, 2017 (in Ukrainian).

\section{(c) BY-NC-SA}

This work is licensed under Creative Commons Attribution-NonCommercial-ShareAlike 4.0 International License. 